\title{
The Main Predicament and Path Choice of Higher Education Professional Accreditation in Jilin Province
}

\author{
Zehui An \\ The Higher Education Research Institute of Jilin Agricultural University; Jilin Changchun; China \\ zehuian@126.com
}

Keywords: Professional accreditation; Dynamic monitoring; Dynamic adjustment

\begin{abstract}
It has been more than 20 years since from China's professional evaluation of 1993. The professional accreditation of professionals in Jilin Province presents development trend, but compared with other provinces, autonomous regions and municipalities, the number of certified professionals in colleges and universities of Jilin Province is less than normal. Professional accreditation in the exploration and development stage. At the same time, colleges and universities lack of professional accreditation awareness, emphasizing evaluation and neglecting rectification. The professional distribution of the colleges and universities that have passed the accreditation is out-of-balance. The regional professional accreditation practice exploration needs to be strengthened. In order to solve the problems above, this paper puts forward the establishment of dynamic monitoring and comprehensive evaluation system of the undergraduate professionals in colleges and universities, establishing the release system of professional quality evaluation results of colleges and universities, warning withdrawal and dynamic adjustment mechanism of undergraduate professionals, the mechanism of professional accreditation information management system and professional accreditation incentive mechanism and other suggestions.
\end{abstract}

\section{Introduction}

With the popularization of higher education, higher education is facing enormous pressure on government and social accountability. It is the common experience of higher education development and quality construction in the world to promote the improvement of education quality through the assessment and accreditation. Professional accreditation has become an important means of guaranteeing the quality of higher education in various countries. Under the background of China's joining the "Washington Agreement" and comprehensively promoting the accreditation of engineering education, it is of great significance for improving the professional education to analyze the status quo of professional accreditation of higher education in the region.

Specialized/Professional Accreditation refers to the professional accreditation carried out by professional accreditation authorities in a professional field for the vocational professional education (Programmatic) opened by higher education institutions. It's usually done by specialized associations and the educators in certain field together, to provide quality assurance for relevant personnel to enter the preparatory education for specialized occupations. [1]It mainly evaluates the professional students' training objectives, the quality of education, teaching staff, curriculum setting, experimental equipment, teaching management, various teaching documents and original materials and so on, aiming at specific professional or specialized school. In terms of nature, professional accreditation is a kind of conformity assessment, rather than the optimal evaluation, it is to check if the professional meet the minimum standards. Therefore, professional accreditation only has 2 results, namely passed or failed, but no grade or level difference. Passing the accreditation only means that the accreditation profession has achieved the lowest quality standards.

China has started higher education professional accreditation pilot work from the end of last century, and now there are three categories of professional accreditation that is formally carried out: Firstly, the Ministry of Construction began to carry out civil engineering assessment (accreditation)in 1993, including six professional accreditation: civil engineering, architecture, construction environment and energy, engineering management, water supply and drainage and 
urban and rural planning in 1993. As of the end of 2014 has 26 provinces, municipalities and autonomous regions 101 colleges and universities received the Housing and Construction Department of professional accreditation. [2]Secondly, the Ministry of Education began engineering education professional accreditation, including mechanical design and manufacturing and automation, electrical engineering and automation, computer science and technology, chemical engineering and technology, safety engineering, totally 38 engineering majors in 2006. As of the end of 2014, 101 colleges and universities in 25 provinces, autonomous regions and municipalities directly passed the engineering education professional accreditation. Only in 2014, there are 25 colleges and universities participating in the accreditation.[3]The third is medical education accreditation. In order to strengthen the macro management of medical education quality, promote the medical teaching reform, improve the quality of medical professionals training, establish China's medical education accreditation system and carry out medical professional accreditation work, the Ministry of Education set up the Ministry of Education Medical Education Accreditation Experts Comity 2008. It specifically involves six majors: clinical medicine, oral medicine, nursing, pharmacy, traditional Chinese medicine, and traditional Chinese pharmacology. On the whole, in recent years, China's higher education professional accreditation presents a rapid development trend.[4]

\section{The Present Situation of Professional Accreditation of Higher Education in Jilin Province}

From the data that the universities passing professional accreditation in Jilin (as of 2014), the existing three types of professional accreditation in China are involved, in which the 38 majors in engineering education, there are 9 majors passing the accreditation; for the 6 majors in medical education, there are 2 majors in Jilin Province passing the accreditation; for the 6majors in civil engineering, all the relevant universities in Jilin Province passed. The universities that have passed the accreditation include both the universities directly under Ministry of Education and the province. Overall, the number of certified universities in Jilin Province is not too much, but from the time firstly passing the accreditation, most of the majors passed the accreditation in 2010, which shows that in recent years, professional accreditation gets more attentions from universities and majors, higher education professional accreditation is still in the stage of exploration and development.

Compared with the other provinces, autonomous regions and municipalities directly under the central government, the number of colleges and universities that passed engineering education professional accreditation 2, ranked No.15; the number of majors that passed the accreditation is 10 , ranked No.12. And the number of colleges and universities passed clinical medicine accreditation (Jilin University). Overall, the level of higher education accreditation in Jilin province is on ordinary level. 
Table 1 List of ordinary universities that has passed the professional accreditation in Jilin Province

\begin{tabular}{|c|c|c|c|c|c|c|}
\hline university & Item & Time & Major & Conclusion & Valid date & Total majors \\
\hline \multirow{11}{*}{ Jilin University } & \multirow{9}{*}{$\begin{array}{l}\text { Engineering } \\
\text { education }\end{array}$} & 2014 & $\begin{array}{l}\text { Exploration Technology and } \\
\text { Engineering }\end{array}$ & passed accreditation & 3years & \multirow{11}{*}{10} \\
\hline & & 2013 & Environmental Engineering & passed accreditation & 3years & \\
\hline & & 2013 & $\begin{array}{l}\text { Measurement and Control } \\
\text { Technology and Instruments }\end{array}$ & passed accreditation & 3years & \\
\hline & & 2012 & $\begin{array}{l}\text { Food science and } \\
\text { engineering }\end{array}$ & $\begin{array}{l}\text { Agree to extend the valid } \\
\text { period }\end{array}$ & 3years & \\
\hline & & 2012 & $\begin{array}{l}\text { Mechanical Engineering } \\
\text { and Automation }\end{array}$ & passed accreditation & 6years & \\
\hline & & 2012 & Vehicle Engineering & passed accreditation & 6years & \\
\hline & & 2011 & $\begin{array}{l}\text { Computer Science and } \\
\text { Technology }\end{array}$ & passed accreditation & 6years & \\
\hline & & 2010 & $\begin{array}{l}\text { Hydrology and Water } \\
\text { Resources Engineering }\end{array}$ & passed accreditation & 6years & \\
\hline & & 2009 & $\begin{array}{l}\text { Food Science and } \\
\text { Engineering }\end{array}$ & passed accreditation & 3years & \\
\hline & \multirow{2}{*}{$\begin{array}{l}\text { Medical } \\
\text { education }\end{array}$} & 2011 & Clinical Medicine & passed accreditation & & \\
\hline & & 2010 & Nursing & passed accreditation & & \\
\hline $\begin{array}{l}\text { Yanbian } \\
\text { University }\end{array}$ & $\begin{array}{l}\text { Medical } \\
\text { education }\end{array}$ & 2014 & Nursing & passed accreditation & & 1 \\
\hline \multirow{2}{*}{$\begin{array}{l}\text { Jilin Institute of } \\
\text { Chemical } \\
\text { Technology }\end{array}$} & \multirow{2}{*}{$\begin{array}{l}\text { Engineering } \\
\text { education }\end{array}$} & 2012 & $\begin{array}{l}\text { Chemical Engineering and } \\
\text { Technology }\end{array}$ & $\begin{array}{l}\text { Agree to extend the valid } \\
\text { period }\end{array}$ & 3years & \multirow{2}{*}{1} \\
\hline & & 2009 & $\begin{array}{l}\text { Chemical Engineering and } \\
\text { Technology }\end{array}$ & passed accreditation & 3years & \\
\hline \multirow{6}{*}{$\begin{array}{l}\text { Jilin Jianzhu } \\
\text { University }\end{array}$} & \multirow{6}{*}{$\begin{array}{l}\text { Civil } \\
\text { engineering }\end{array}$} & & Architecture & Passed the assessment & $\begin{array}{l}2014.5-2018 \\
.5\end{array}$ & \multirow{6}{*}{6} \\
\hline & & & $\begin{array}{l}\text { Urban and Regional } \\
\text { Planning }\end{array}$ & Passed the assessment & $\begin{array}{l}2014.5-2018 \\
.5\end{array}$ & \\
\hline & & & Civil Engineering & Passed the assessment & $\begin{array}{l}2011.5-2016 \\
.5\end{array}$ & \\
\hline & & & Water Supply And Drainage & Passed the assessment & $\begin{array}{l}2014.5-2019 \\
.5\end{array}$ & \\
\hline & & & $\begin{array}{l}\text { Construction Environment } \\
\text { and Energy Application } \\
\text { Engineering }\end{array}$ & Passed the assessment & $\begin{array}{l}2014.5-2019 \\
.5\end{array}$ & \\
\hline & & & $\begin{array}{l}\text { Professional Assessment of } \\
\text { Engineering Management }\end{array}$ & Passed the assessment & $\begin{array}{l}2014.5-2019 \\
.5\end{array}$ & \\
\hline $\begin{array}{l}\text { Changchun } \\
\text { Institute } \\
\text { Technology }\end{array}$ & $\begin{array}{l}\text { Civil } \\
\text { engineering }\end{array}$ & & Civil Engineering & Passed the assessment & $\begin{array}{l}2013.5-2018 \\
.5\end{array}$ & 1 \\
\hline
\end{tabular}

Note: as of 2014, the data of "medical education" is a little lagging. 
Table 2 List of the universities that have passed the professional accreditation of engineering education in each province, municipality

\begin{tabular}{llllllll}
\hline No. & $\begin{array}{l}\text { province, } \\
\text { municipality }\end{array}$ & $\begin{array}{l}\text { Passed } \\
\text { universities } \\
\text { No. }\end{array}$ & $\begin{array}{l}\text { Passed } \\
\text { majors } \\
\text { No. }\end{array}$ & No. & $\begin{array}{l}\text { province, } \\
\text { municipality }\end{array}$ & $\begin{array}{l}\text { Passed } \\
\text { universities } \\
\text { No. }\end{array}$ & $\begin{array}{l}\text { Passed } \\
\text { majors } \\
\text { No. }\end{array}$ \\
\hline 1 & Beijing & 16 & 25 & 14 & Henan & 3 & 8 \\
2 & Jiangsu & 11 & 24 & 15 & Jilin & $\mathbf{2}$ & $\mathbf{9}$ \\
3 & Liaoning & 8 & 20 & 16 & Guangdong & 2 & 8 \\
4 & Shanxi & 8 & 14 & 17 & Chongqing & 2 & 5 \\
5 & Shanghai & 6 & 14 & 18 & Shaanxi & 2 & 4 \\
6 & Sichuan & 5 & 12 & 19 & Jiangxi & 2 & 3 \\
7 & Hunan & 5 & 11 & 20 & Hebei & 2 & 2 \\
8 & Shandong & 5 & 10 & 21 & Yunnan & 1 & 8 \\
9 & Hubei & 5 & 10 & 22 & Inner Mongolia & 1 & 2 \\
10 & Anhui & 3 & 12 & 23 & Guizhou & 1 & 2 \\
11 & Heilongjiang & 3 & 10 & 24 & Gansu & 1 & 1 \\
12 & Tianjin & 3 & 8 & 25 & Fujian & 1 & 1 \\
13 & Zhejiang & 3 & 8 & & & & \\
\hline
\end{tabular}

Note: as of 2014

Table 3: List of the universities that have passed the professional accreditation of clinical medicine education in each province, municipality

\begin{tabular}{llllll}
\hline No. & $\begin{array}{l}\text { province, } \\
\text { municipality }\end{array}$ & $\begin{array}{l}\text { Passed } \\
\text { universities } \\
\text { No. }\end{array}$ & No. & $\begin{array}{l}\text { province, } \\
\text { municipality }\end{array}$ & $\begin{array}{l}\text { Passed } \\
\text { universities } \\
\text { No. }\end{array}$ \\
\hline 1 & Zhejiang & 6 & 11 & Hebei & 2 \\
2 & Hubei & 5 & 12 & Shandong & 2 \\
3 & Liaoning & 4 & 13 & Fujian & 1 \\
4 & Guangdong & 4 & 14 & Gansu & 1 \\
5 & Guangxi & 3 & 15 & Hainan & 1 \\
6 & Heilongjiang & 3 & 16 & Jilin & 1 \\
7 & Hunan & 3 & 17 & Shanxi & 1 \\
8 & Jiangsu & 3 & 18 & Sichuan & 1 \\
9 & Jiangxi & 3 & 19 & Tianjin & 1 \\
10 & Beijing & 2 & 20 & Chongqing & 1 \\
\hline
\end{tabular}

Note: as of 2015

\section{The Main Dilemma of Professional Accreditation of Higher Education in Jilin Province}

Colleges and Universities Lack of the Consciousness of Professional Accreditation. It has been more than 20 years since China started professional assessment pilot in 1993, but most of colleges and universities in Jilin Province, especially the local undergraduate institutions and managers learn less about the accreditation content, standards and program, lack of awareness of the importance of professional accreditation. "Accreditation is useless" thinking is more common. In addition, the accreditation needs the voluntary application of the colleges and universities, and many of them lack confidence in the quality of their own professional education, or stick to the existing professional curriculum system and teaching mode, so the initiative participating in professional accreditation is weak. On the one hand, because the professional accreditation of colleges and universities in our country is mainly implemented by the government and the education department, and the government is the organizer and implementer in one, directly 
involved in the management of their own internal affairs. Under the supervision and regulation, college autonomous right is partially vacant. At the same time, the accreditation experts are hired by the relevant administrative departments, with a clear official nature, and the certified majors are always in a passive state to deal with the examination, so colleges and universities have become a certified object of supervision. This kind of unified administrative way, to a certain extent, weakens the initiative to participate in the accreditation of colleges and universities.[5]

Emphasizing Assessment, Neglecting Rectification. Professional accreditation performed in turn with self-evaluation of colleges and universities, experts' on-site inspection and rectification. Accreditation rectification means the colleges and universities that have passed accreditation should carefully study the problems and short comings identified in the accreditation report and take effective measures to improve. The refore, rectification is the key point to improve the professional quality and personnel training level. However, from the practice, after passed the accreditation, many colleges and universities, the "improvement" is only in the form of improvement measures, which have not been implemented. This"emphasizing accreditation and neglecting rectification" phenomenon is bound to lose the significance of professional accreditation, detrimental to the development of colleges and universities. For the reasons, on the one hand, the utilitarianism to apply for accreditation in colleges and universities is flooding. In the existing university management mode, they take participating in accreditation as an administrative task, so passed accreditation is perfect. They have not yet recognized the important role of professional accreditation in improving the quality of professional teaching. [6] On the other hand, due to the imperfect construction of the internal system of colleges and universities, it has not yet formed the internal quality assurance mechanism which is compatible with the professional accreditation, so that the improvement measures cannot be effectively implemented in teaching practice.[7]

Distribution Unbalance of the Majors Passed Accreditation. As of 2013, there are total 37 undergraduate colleges and universities, including 2 colleges and universities directly under MOE, 23 provincial colleges and universities, 12 private colleges and universities (including independent colleges, the same below). There are only 5 colleges and universities that involve three professional accreditations. From the professional perspective, there are 38 majors getting engineering education accreditation, 9 in Jilin Province, accounting for 23.68\%, of which Jilin University takes up 8, accounting for $88.89 \%$ of the total.[8] One of the reasons for this phenomenon is the existing professional accreditation needs the form of voluntary application, 985 or the colleges and universities directly under MOE have better teaching quality and have a certain initiative in participating in professional accreditation, and local institutions, especially private schools, due to the constraint of school conditions, level of teaching, the quality of students and other factors, they lack of confidence in the participation of accreditation, and even some more likely to do the avoidance types of responses. Therefore, in order to promote the overall improvement of professional education quality, China should strengthen the professional accreditation theory and security system research. Although there is a general policy to carry out professional accreditation from the national level, but the professional level is still lack of professional accreditation rules and regulations within the university. Professional accreditation has not yet been regarded as an important professional education within the quality assurance system to be implemented. Organization, institutional structure, etc. have not yet docked with the international. Regulations for the implementation of professional accreditation system involves little, making the professional accreditation system in the implementation has no rules to follow, but also making the implementation of professional accreditation of colleges and universities lack of legal protection.

Lack of Regional Practice and Exploration of Professional Accreditation. In recent years, the provinces explore actively in the aspect of regional professional accreditation. In 2012, Liaoning firstly launched "Professional Comprehensive Evaluation of Undergraduate Course in Common Colleges and Universities", made the basic information of each college professional education public, allow the society inquiring information. The evaluation system is prepared as majors, and the whole majors in Jinlin province are organized for professional comprehensive evaluation, and the evaluated results are issued to the society, vigorously promoting the major adjustment of 
universities and colleges, evoking big repercussion, and the national ministry of education gave special instructions.

In 2014, Hubei province carried out the evaluation work of undergraduate majors, and in accordance with the separation principle of management, applying and assessment, the special assessment of undergraduate majors are commissioned Education Science Research Institute of Hubei Province to carry out the independent third party assessment, and according to the way of "annual planning, pilot first, step-by-step implementation" to advance gradually, evaluation objects are all the undergraduate majors has been set up in Hubei. The focus is the majors with more points, enormous quantity, and wide coverage or relatively saturated social demand. Jiangxi province has formed acomprehensive evaluation expert guidance committee of ordinary undergraduate majors in colleges and universities, fully launching the undergraduate professional evaluation work.Other wise, Guangdong, Chongqing and so on carried out the famous-brand major assessment. Hainan province and Henan province carried out the assessment of undergraduate major newly established in colleges and universities. Either from the perspective of midland or the whole country, although the professional monitoring and evaluation practice of each province is not completely professional accreditation, they have some characteristics of professional accreditation, resonating well in society. Jilin province should establish professional assessment or accreditation system for Jilin.

\section{Suggestions on Jinlin Province Establishing Regional Professional Accreditation System}

Jilin Province undergraduate major dynamic monitoring and comprehensive evaluation system is established and large data platform and technology is used for dynamic monitoring of the province university professional quality. Based on the data, all undergraduate professional comprehensive assessment or accreditation is carried out annually.

Undergraduate major early warning exit and dynamic adjustment mechanism is established, and the majors with relatively saturated needs are required to adjust. For the professional quality cannot meet the basic assessment standards, early warning will be proposed. If its till cannot meet the requirements of standard requirements after rectification, the majors should be terminated.

Professional certification incentive mechanism is established. Through increasing funding and other incentives, colleges and universities are encouraged to actively participate in professional certification, and strengthen their own professional education information construction, constantly improving the professional education certification technology and methods to form a professional education quality assurance system inside the colleges and universities with accreditation as the method, laying foundation for professional education with external certification.[9]

Promote the establishment of professional certification information management system in colleges and universities. Take collection of undergraduate professional status data as a prerequisite to promote the establishment of professional certification information management system. Standardize information management. According to the certification program requirements, the system collects information and makes verification for it. Order, process and analyze certification conclusions timely to ensure that the information objectivity, authenticity and effectiveness. On this basis, professional certification information publish system on a regular basis is established, including various accreditation information of certification preparation phase, implementation phase and results processing phase. The professional certification analysis report and professional education status data will be published inside the colleges and universities through the campus network and other ways within the universities.[10]

\section{Acknowledgements}

Supported by Youth Foundation of Jilin Agricultural University (No.201652); Supported by Jilin Association of Higher Education (No.JGJX2016D38) 


\section{References}

[1] T.Yao, H.Wang, Y.G.She : University Education Science,No.4,2014,p.28. (In Chinese)

[2] Information on http://www.mohurd.gov.cn/jsrc/zypg/201506/t20150609_221175.html

[3] Information on http://cn.ceeaa.org.cn/index.php(In Chinese)

[4] Information on http://ecame.bjmu.edu.cn/byxw/index/newsList.do(In Chinese)

[5] D.M.Yuan: Journal of Educational Science of Hunan Normal University, Vol.12(2013)No.4,p.87. (In Chinese)

[6] D.M.Yuan: Forum on Contemporary Education,No.3,2015,p.23. (In Chinese)

[7] D.M.Chen, Z.G.Zhou, Z.Y.Yan: Journal of Vocational Education,No.33,2014,p.66. (In Chinese)

[8] Information on http://cn.ceeaa.org.cn/index.php(In Chinese)

[9] J.Lu: Heilongjiang Researches on Higher Education,No.11,2015,p.18. (In Chinese)

[10] D.M.Yuan: Forum on Contemporary Education,No.3,2015,p.23. (In Chinese) 